\title{
$\mathrm{K}_{2} \mathrm{O} \cdot \mathbf{A l}_{2} \mathbf{O}_{3} \cdot \mathrm{SiO}_{2}$ ¿ $\mathrm{K}_{2} \mathrm{O} \cdot \mathrm{Al}_{2} \mathrm{O}_{3}$ ¿について
}

\author{
山口明良 \\ (名古絰工業大学)
}

\section{On the Compound $\mathrm{K}_{2} \mathrm{O} \cdot \mathrm{Al}_{2} \mathrm{O}_{3} \cdot \mathrm{SiO}_{2}$ and $\mathrm{K}_{2} \mathrm{O} \cdot \mathrm{All}_{2} \mathrm{O}_{3}$}

\author{
By \\ Akira YAMAGUCHI \\ (Nagoya Institute of Technology, Nagoya, Japan)
}

著者は前報1でムライトおよびコランダムの $\mathrm{K}_{2} \mathrm{CO}_{3}$ 蒸 気による侵蝕について報告した際，アルミン酸カリが生 成することを報告した．しかしながら図一に示した（a） コランダムが $1200^{\circ} \mathrm{C} の \mathrm{~K}_{2} \mathrm{CO}_{3}$ 蒸気によって侵蝕され たもの打よび (b) ムライトが $1100^{\circ} \mathrm{C} の \mathrm{~K}_{2} \mathrm{CO}_{3}$ 蒸気 で侵蝕されたものそれぞれの粉末 $\mathrm{X}$ 線分析結果を詳細 に検討すると，アルミン酸カリと同定したものの回折図 形に相違のあることがわかった。しかるにムライトが $\mathrm{K}_{2} \mathrm{CO}_{3}$ 蒸気によって侵蝕されたものには $\mathrm{K}_{2} \mathrm{O} \cdot \mathrm{Al}_{2} \mathrm{O}_{3}$ 。 $\mathrm{SiO}_{2}$ 拉よびそれと $\mathrm{K}_{2} \mathrm{O} \cdot \mathrm{Al}_{2} \mathrm{O}_{3}$ の固溶体が生成してい ることが予想されたので，本寒験はこれらのことについ て明らかにするために行なった実験である。

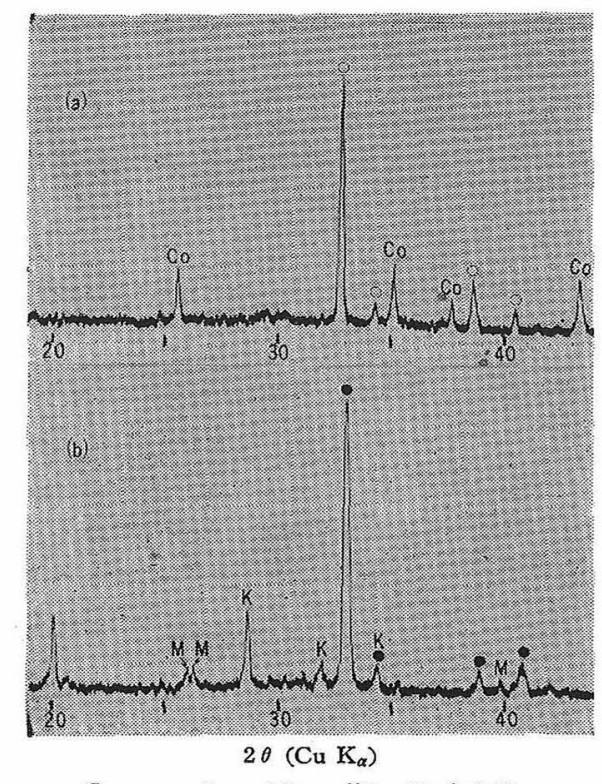

Co : corundum, $\mathrm{M}:$ mullite, $\mathrm{K}$ : kalsilite

Fig. 1. X-ray diffraction patterns of the corundum attacked by $\mathrm{K}_{2} \mathrm{CO}_{8}$ vapor at $1200^{\circ} \mathrm{C}$ (a), and the mullite by $\mathrm{K}_{2} \mathrm{CO}_{s}$ vapor at $1100^{\circ} \mathrm{C}$ (b).
$\mathrm{K}_{2} \mathrm{O} \cdot \mathrm{Al}_{2} \mathrm{O}_{3} \cdot \mathrm{SiO}_{2}$ について Weyberg ${ }^{2)}$ が最初にその 存在を報告し, その後 Schairer と Bowen ${ }^{3)} か ゙ ~ \mathrm{~K}_{2} \mathrm{O} \cdot \mathrm{SiO}_{2}$ と $\mathrm{Al}_{2} \mathrm{O}_{3}$ の混合物から合成を試み， $1700^{\circ} \mathrm{C}$ 以上の高融 点を有して均一相を得るのが困難であることおよび八面 体に結晶し，屈折率は 1.540 であることを報告してい る.

一方, $\mathrm{K}_{2} \mathrm{O} \cdot \mathrm{Al}_{2} \mathrm{O}_{3}$ について Brownmiller ${ }^{4}$ が $7.69 \AA$ の格子定数の等軸晶系であり, 約 1.605 の屈折率を有 することを，また Schairer と Bowen は $1650^{\circ} \mathrm{C} て ゙$ 解 離することを報告している.

本実験は $\mathrm{K}_{2} \mathrm{O} \cdot \mathrm{Al}_{2} \mathrm{O}_{3} \cdot 3 \mathrm{H}_{2} \mathrm{O}$ (c.p) 約 $800^{\circ} \mathrm{C}$ 亿层焼 して完全に無水物にしたものと $\mathrm{SiO}_{2}$ (沈降製無水理酸 特級試薬) とを混合し, $\mathrm{K}_{2} \mathrm{O} \cdot \mathrm{Al}_{2} \mathrm{O}_{3}$ と $\mathrm{K}_{2} \mathrm{O} \cdot \mathrm{Al}_{2} \mathrm{O}_{3} \cdot \mathrm{SiO}_{2}$ の種々の割合のもの, すなわち $\mathrm{SiO}_{2}$ の混合率が 23.4 wt $\%\left(\mathrm{~K}_{2} \mathrm{O} \cdot \mathrm{Al}_{2} \mathrm{O}_{3} \cdot \mathrm{SiO}_{2}\right), 18 \%, 12 \%, 6 \%$ および $3 \%$ のものを用意した。そしてこれらの混合物をプレス成形 し $1300^{\circ} \mathrm{C}$ で 15 時間焼成して, 再度粉砕プレス成形し $1300^{\circ} \mathrm{C}$ で 5 時間哑成した後徐冷したものを試料とし た.

上記生成化合物はいずれも複屈折はなく，またX線分 析結果からも等軸晶系であることを示した。

図 -2 に各試料の $2 \theta\left(\mathrm{Cu} \mathrm{K} \mathrm{K}_{\alpha}\right)$ が $19 \sim 44^{\circ}$ の範囲の 粉末 X.線回折図形を示した. $\mathrm{K}_{2} \mathrm{O} \cdot \mathrm{Al}_{2} \mathrm{O}_{3}$ は Brownmiller が記述しているように，非常に吸湿性に富み，結晶の表 面に変質相を生成したために不明な弱い回折線を認めて いるが，本実験に沶いてを $\mathrm{SiO}_{2}$ 含有率の低い試料では 不明な弱い回折線が認められるが，これは $\mathrm{K}_{2} \mathrm{O} \cdot \mathrm{Al}_{2} \mathrm{O}_{3}$ の場合と同様に吸湿性のために結晶表面が変質したため と考えられる. しかし $\mathrm{SiO}_{2}$ の含有率の高いものほど吸 湿性は少なくなっていた．また $\mathrm{SiO}_{2}$ 含有率が高くなる に従って $(\mathrm{hkl}=211),(300) ，(310) ，(311)$ などの各 面の回折線は弱くなるかあるいは消滅する。一方新たに $\mathrm{K}_{2} \mathrm{O} \cdot \mathrm{Al}_{2} \mathrm{O}_{3}$ には現われない (111) 面の回折線 (2 $\theta=$ 


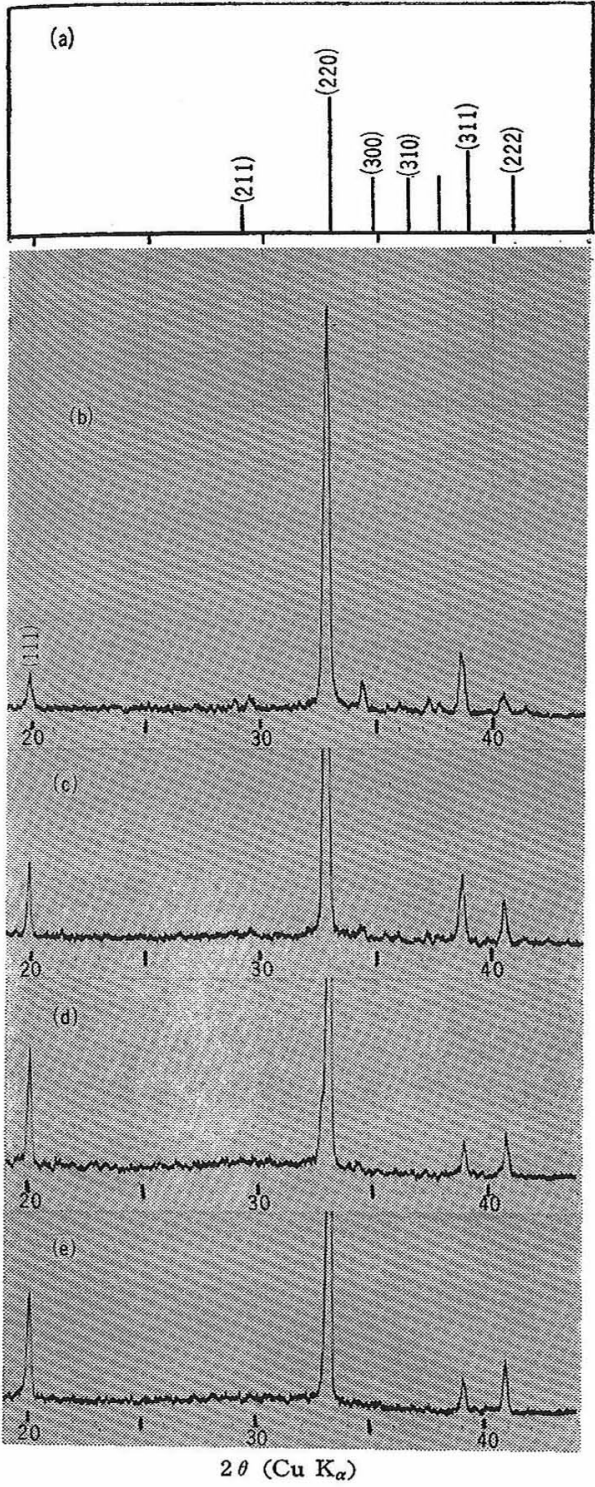

(a) $\mathrm{K}_{2} \mathrm{O} \cdot \mathrm{Al}_{2} \mathrm{O}_{3}$ (by Brownmiller)

(b) (d) $\quad \mathrm{K}_{2} \mathrm{O} \cdot \mathrm{Al}_{2} \mathrm{O}_{3}-\mathrm{K}_{2} \mathrm{O} \cdot \mathrm{Al}_{2} \mathrm{O}_{3} \cdot \mathrm{SiO}_{2}$ solid solution

$\begin{array}{lll}\text { (b) } 3 \mathrm{wt} \% \mathrm{SiO}_{2} & \text { (c) } 6 \mathrm{wt} \% \mathrm{SiO}_{2} & \text { (d) } 18 \mathrm{wt} \% \mathrm{SiO}_{2}\end{array}$

(e) $23.4 \mathrm{wt} \% \mathrm{SiO}_{2}\left(\mathrm{~K}_{2} \mathrm{O} \cdot \mathrm{Al}_{2} \mathrm{O}_{3} \cdot \mathrm{SiO}_{2}\right)$

Fig. 2. X-ray diffraction patterns of $\mathrm{K}_{2} \mathrm{O} \cdot \mathrm{Al}_{2} \mathrm{O}_{3}$ $\mathrm{K}_{2} \mathrm{O} \cdot \mathrm{Al}_{2} \mathrm{O}_{3} \cdot \mathrm{SiO}_{2}$, and their solid solution.

$20^{\circ}$ 付近) が現われ，また(222) 面の回折線は強くなる. そしてすべての回折線は高角側にずれを生じ，格子定数 の変化を求めると図 -3 のよ5に直線的に変化する（た だし $\mathrm{K}_{2} \mathrm{O} \cdot \mathrm{Al}_{2} \mathrm{O}_{3}$ および $3 \mathrm{wt} \% \mathrm{SiO}_{2}$ 含有率試料の值 は吸湿性が特にあり，水和物の回折線も認められ，純粋 にその組成のものとは言(難い).これより $\mathrm{K}_{2} \mathrm{O} \cdot \mathrm{Al}_{2} \mathrm{O}_{3}$ 。 $\mathrm{SiO}_{2}$ は面心立方でその格子定数は $7.650 \pm 0.005 \AA$ であ り，一方 $\mathrm{K}_{2} \mathrm{O} \cdot \mathrm{Al}_{2} \mathrm{O}_{3}$ の格子定数は外挿して求めると，
窯業協会誌 78［2] 197075

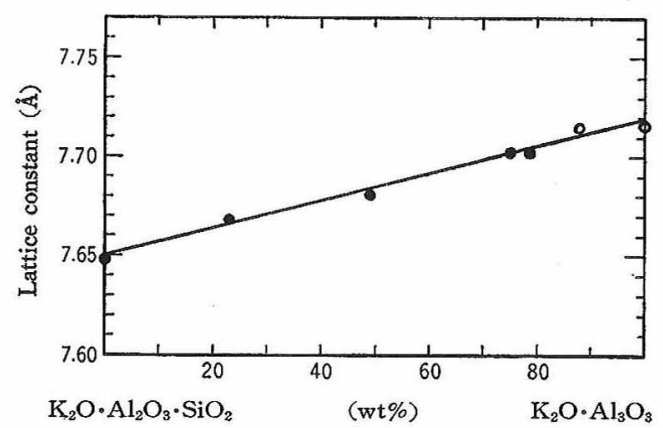

Fig. 3. Lattice constants of $\mathrm{K}_{2} \mathrm{O} \cdot \mathrm{Al}_{2} \mathrm{O}_{3} \cdot \mathrm{SiO}_{2}-\mathrm{K}_{2} \mathrm{O} \cdot \mathrm{Al}_{2} \mathrm{O}_{8}$ solid solution.

$7.720 \pm 0.005 \AA$ となり Brownmiller が求めた $7.69 \AA$ よりも高い值を示した。

別に, $\mathrm{SiO}_{2}$ 含有率が $25 \mathrm{wt} \%$ のものについて同様な 実験を行なった結果は新たに斜方カリオフィライトの回 折線が現われていた。

以上のことにより $\mathrm{K}_{2} \mathrm{O} \cdot \mathrm{Al}_{2} \cdot \mathrm{SiO}_{2}$ が結晶として存在 し, それは $\mathrm{K}_{2} \mathrm{O} \cdot \mathrm{Al}_{2} \mathrm{O}_{3}$ と完全な固溶体を形成し, $\mathrm{KAlSiO}_{4}$ とは固溶しないことが判った.すなわち $\mathrm{K}_{2} \mathrm{O}$ 。 $\mathrm{Al}_{2} \mathrm{O}_{3}$ は, Barth ${ }^{5)}$ および Burger ${ }^{6)}$ の報告にあるよう に, 高温型クリストバライトの誘導体であり, $\mathrm{KAlSiO}_{4}$ は高温型トリディマイトの誘導体であるが $\mathrm{K}_{2} \mathrm{O} \cdot \mathrm{Al}_{2} \mathrm{O}_{3}$ ・ $\mathrm{SiO}_{2}$ \& $\mathrm{K}_{2} \mathrm{O} \cdot \mathrm{Al}_{2} \mathrm{O}_{3}$ と完全な固溶体を作ることから考 えて, $\mathrm{K}, \mathrm{O} \cdot \mathrm{Al}_{2} \mathrm{O}_{3}$ と似た構造を有すると考えられ，卜 リディマイト誘導体の $\mathrm{KAlSiO}_{4}$ とは固溶しないものと 考えられる。

これらのことから 図-1 に示す生成物 $(\mathrm{O}$ ，の記号 をつけたもの) を同定すると, (a) は $\mathrm{K}_{2} \mathrm{O} \cdot \mathrm{Al}_{2} \mathrm{O}_{3}$ であ り, (b) は $\mathrm{K}_{2} \mathrm{O} \cdot \mathrm{Al}_{2} \mathrm{O}_{3} \cdot \mathrm{SiO}_{3}-\mathrm{K}_{2} \mathrm{O} \cdot \mathrm{Al}_{2} \mathrm{O}_{3}$ 固溶体であっ た. そしてムライトが $\mathrm{K}_{2} \mathrm{CO}_{3}$ 蒸気によって侵蝕される 場合生成する $\mathrm{K}_{2} \mathrm{O} \cdot \mathrm{Al}_{2} \mathrm{O}_{3} \cdot \mathrm{SiO}_{2}-\mathrm{K}_{2} \mathrm{O} \cdot \mathrm{Al}_{2} \mathrm{O}_{3}$ 固溶体は, 格子定数の変化から求めると侵蝕が進むに従って $\mathrm{K}_{2} \mathrm{O}$. $\mathrm{Al}_{2} \mathrm{O}_{3}$ 成分の多い固溶体が生成した.

\section{文献}

1）山口明良, 大河原晋, 山中昭広, 蒸協 77 [11] 357-66 (1969).

2) Weyberg, Z., Neues Jahrb., Centralble., 326-30 (1908); J.F. Schairer and N.L. Bowen, Am. J. Sci., 253, 734 (1955).

3) J.F. Schairer and N.L. Bowen, ibid., 253, 681-746 (1955).

4) L.T. Brownmiller, Am. J. Sci., 26, 260-77 (1935); Tom. F.W. Barth, J. Chem. Phys., 3, 323-25 (1935).

5) Tom. F.W. Barth, ibid.

6) M.J. Burger, Am. Mine., 39, 600-14 (1954).

(9/24/1969 受付) 